UDC 628.17:628.33:658.26:681.5

DOI: https://doi.org/10.20535/2218-93002322018144959

\title{
INDUSTRIAL WATER USAGE NETWORKS DESIGN PROCEDURE
}

\author{
A. Shakhnovsky, O. Kvitka \\ National Technical University of Ukraine, "Igor Sikorsky Kyiv Polytechnic Institute", \\ Kyiv, Ukraine, e-mail: kxtp@kpi.ua
}

The paper addresses some important results as to optimal design of water usage networks. The aim was to minimize freshwater consumption by water re-use at minimum total flow-rate of water streams among processes and small number of process interconnections. The design approach was based on mixed-integer nonlinear multi-objective programming problem of superstructure optimization. The superstructure includes all possible structures and consists of mass balances of mixers, splitters, water users and partial treatment processes. The general solution algorithm of optimization was outlined. The optimal network design procedure is described. The examples presented show that the approach is robust technique for the synthesis of water usage networks.

Keywords: water usage network, design, wastewater, optimization, mathematical programming model.

\section{Wastewater Reduction via Process Integration}

The current philosophy of environmental protection in industry is to eliminate or to reduce wastes "at heart" of technology (in contrast to traditional end-of-pipe processing). There are several ways to achieve this goal, for example:

- to use another ("environment friendly") technology;

- to apply new processes (e.g. to use apparatus of high performance, to replace water cooling with air-cooling)

Meanwhile, the application of these means is both expensive and time-consuming. The easiest (and relatively cheap) way to deal with wastes in chemical and allied industries is to integrate processes and apparatus. In case of "grassroot" design the integration costs almost nothing. In case of "revamp" (retrofit) scenario the process optimization by integration is also relatively low-cost. The major financial placements are due to modification of the structure of existing system (e.g. new pipes routing). Also, some parameters shall be changed such as pumps rate.

There are two general strategies of optimal synthesis of total integrated plants:

1. "Hierarchical" (insight-based) approach [1-3].

2. "Simultaneous" (superstructure) approach [4-6].

The "simultaneous" approach provides systematic framework for designing optimal plant while the "hierarchical" approach lacks generality and is not fully systematic. Unfortunately, practical application of the simultaneous strategy is quite difficult at present [7] since there is no effective optimization technique that is able to solve huge optimization problems (nonlinear programming problem or mixed-integer nonlinear programming problem). Furthermore, it seems uncertain whether fully automated method such as simultaneous one is flexible enough to manage with the realworld industrial cases.

The existing simultaneous process integration approaches are able to design some subsystems with the help of systematic procedures. Such subsystems are as follows: heat exchanger networks (HENs), mass exchangers networks (MENs), water networks (WNs), utility subsystems, distillation trains and so on - see e.g. [8-10]. In this paper we will concentrate upon water networks. 
Chemical and allied industries are major water consumers. Through stringent environmental protection standards the use of water in industrial processes is going to be more expensive. Consequently, the problem of reducing freshwater usage becomes of vital importance.

The problem of minimizing water usage by process integration is termed "water network design". The water network consists of water using processes such as extraction, distillation, filtration, cooling and steam system, and water treatment processes. Traditionally, such network has the parallel structure where freshwater is fed to water using processes and, then, sent to central treatment station. Such parallel structure with central water treatment station consumes a lot of freshwater and also accounts for the high price of water treatment. By including water reuse and redistributing water treatment operations we can reach even zero water discharge.

\section{Water networks design procedure: the mathematical apparatus}

The original mathematical optimization problem definitions were proposed in $[5,11]$, as well as in [12-17], and others. All these applications contain superstructure-based optimization models of the water usage network. Fig. 1 is given here to illustrate the superstructure, which includes the water usage process and the process of partial water treatment.

Available models are different. They differ from each other by the type of optimization problem (for example, the presence or absence of integer variables), as well as by the type of goal functions. For instance, most models presented [12-14] do not take into account water losses, and several sources of fresh water.
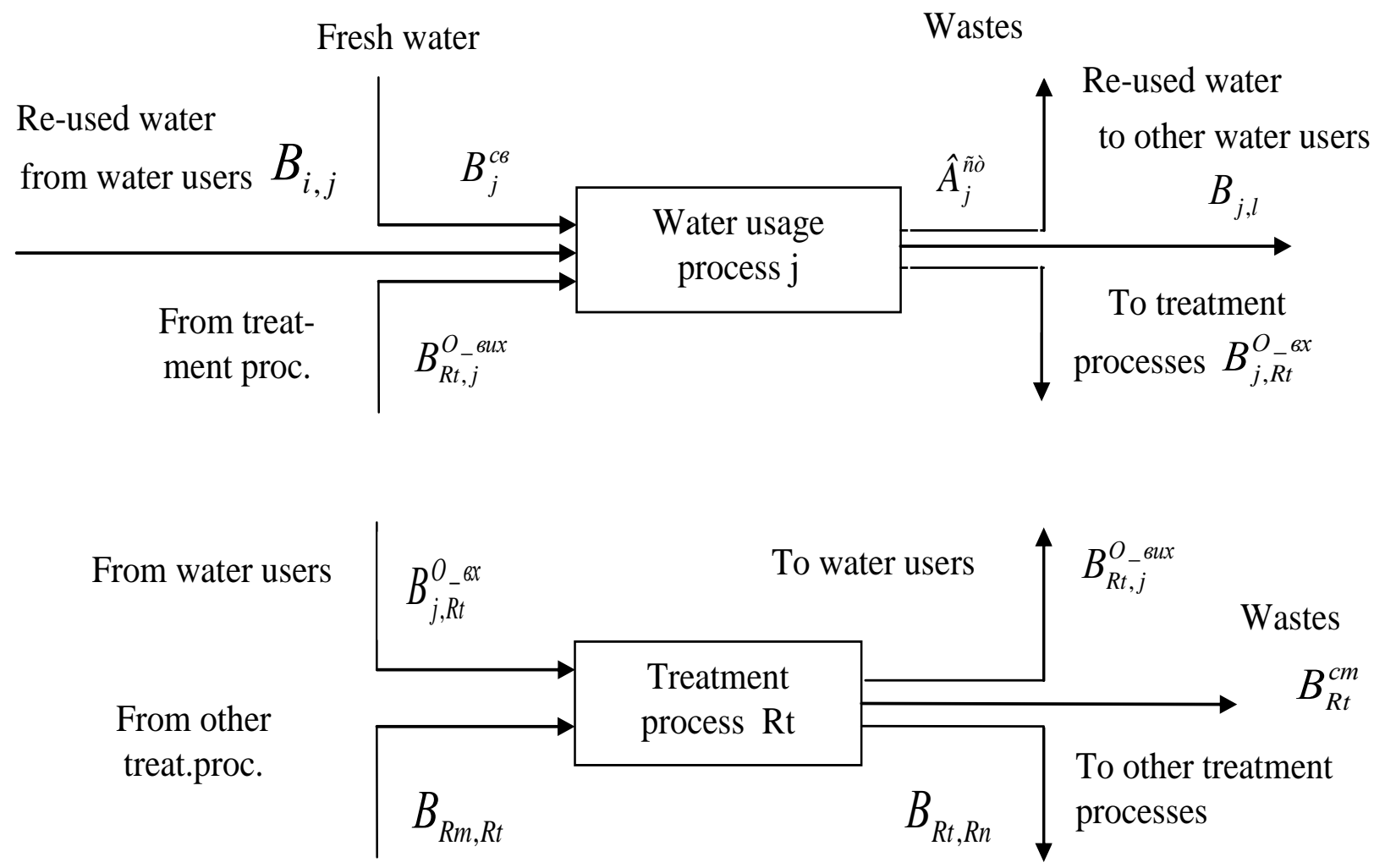

Fig. 1. The section of the superstructure for water usage network design.

An effective model for water usage networks design [12] is suitable for designing water networks with partial treatment of water flows, taking into account the mutual influence between water network units. Minimum fresh water consumption, minimum waste water and minimum pollutant load can be achieved. However, there are some disadvantages of this model:

- it doesn't include water treatment processes; 
- it ignores water losses;

- there are no fixed flow-rates at the inlet of water users;

- several sources of fresh water are not included.

For future reference we decided to apply an optimization model which is the combination of the main mathematical apparatus from $[5,11]$ (proposed by the current authors earlier) and abovementioned mathematical tools [12].

The task of optimization for the synthesis of water usage networks includes several objective functions. The most common performance index for water usage networks applied in the literature is cost of fresh water consumed in the network (1). In order to account for operation and investment cost we also consider minimization of total streams flow-rates of "contaminated" water in interconnections with water using processes (2). Minimization of mass load of contaminant for the treatment processes (3) and number of interconnections (4) are the next objectives.

$$
\operatorname{Min} \sum_{j \in P} B_{d, j}^{C B}
$$

where: $B_{d, j}^{C B}$ is flow-rate of fresh water at the inlet of the process $j$ from the freshwater source $d$. One should notice that in case of a single fresh water source (as it shown in (1)) the goal function is simply the usage of fresh water.

$$
\operatorname{Min} \sum_{R t \in O}\left(\lambda_{R t} \cdot \sum_{j \in \Pi} B_{R t, j}^{O_{-} \text {sux }}\right)
$$

where: ${ }^{\lambda}$ is unit cost of water treatment (weighting factor for the treatment process $R t$ );

$B_{R t, j}^{\hat{I}-a \hat{e} \tilde{o}}$ is water flow-rate from to the treatment process $R t$ water user $j$.

$$
\operatorname{Min} \sum_{R t \in O}\left(\sum _ { j \in \Pi } B _ { R t , j } ^ { O _ { - } B u x } \cdot \sum \left(\left(K_{R t, s}^{B x}-K_{R t, s}^{B u x}\right) \cdot \lambda_{R t, s} \cdot\right.\right.
$$

where: $\lambda_{R t, s}$ is weighting factor for the contaminant $s$ in treatment process $R t$ (the value of weighting factor is determined by influence of the contaminant on capital costs and operating costs), $\sum_{s \in K} \lambda_{R t, s}=1 ; K_{R t, s}^{B x, a}$ is limiting concentration of contaminant $s$ at the inlet of treatment process $R t ; K_{R t, s}^{B u x, a}$ is limiting concentration of contaminant $s$ at the outlet of treatment process $R t$.

$$
\operatorname{Min} \sum_{i \in \Pi} \sum_{j \in \Pi} y_{i, j}+\sum_{R t \in O} \sum_{j \in \Pi} y_{R t, j}^{O_{-} \in u x}+\sum_{j \in \Pi} \sum_{R t \in O} y_{j, R t}^{O_{-} 6 x}+\sum_{R m \in O} \sum_{R t \in O} y_{R m, R t}^{O}+\sum_{j \in \Pi} y_{j}^{c m}+\sum_{R t \in O} y_{R t}^{O_{-} c m}
$$

where: $y_{i, j}$ is current value of the water flow-rate from the water user $i$ to the water user $j ; y_{j, \bar{R} t}^{O{ }^{6 x}}$ is current value of the water flow-rate from the water user $j$ to treatment process $R t ; y_{R t, j}^{O O_{i}}$ is current value of the water flow-rate from treatment process $R t$ to the water user $j ; y^{O}{ }_{R m, R t}$ is current value of the water flow-rate from treatment process $R m$ to treatment process $R t$. 
Optimization problem constraints:

Process water streams mass balance:

$$
\begin{gathered}
\forall j: \sum_{d \in Д} B_{d, j}^{c B}+\sum_{i \in \Pi} B_{i, j}+\sum_{R t \in O} B_{R t, j}^{O_{-} \text {sux }}=B_{j}^{c m}+\sum_{k \in \Pi} B_{j, k}+\sum_{R t \in O} B_{j, R t}^{O_{-} 6 x}+B_{j}^{B m}, \\
i \neq j \quad k \neq j
\end{gathered}
$$

where: $B_{j}^{c m}$ is flow-rate of wastewater at the outlet of water user $j ; B_{j}^{c B}$ is flow-rate of fresh water at the inlet of water user $j ; B_{j, l}$ is flow-rate of wastewater from the outlet of water user $j$ to the inlet of water user $l ; B_{j, R t}^{O{ }_{-} b x}$ is flow-rate of wastewater from the outlet of water user $j$ to the treatment process $R t ; B_{R t, j}^{O_{-}{ }^{6 u x}}$ is flow-rate of partially treated wastewater from the outlet of treatment process $R t$ to the outlet of water user $j$.

Water usage: balance of contaminants:

$$
\begin{aligned}
& \forall j, s: \quad \sum_{d \in Д}\left(B_{d, j}^{c B} \cdot K_{d, s}^{c B}\right)+\sum_{i \in \Pi}\left(B_{i, j} \cdot K_{i, s}^{B u x}\right)+\sum_{R t \in O} B_{R t, j}^{O_{-}-6 u x} \cdot K_{R t, s}^{B u x}=\left(\sum_{d \in Д} B_{d, j}^{c s}+\sum_{i \in \Pi} B_{i, j}+\sum_{R t \in O} B_{R t, j}^{O_{-}-u x x}\right) \cdot K_{j, s}^{B x} \\
& i \neq j \\
& k \neq j
\end{aligned}
$$

$$
\begin{aligned}
& \forall j, s:\left(\sum_{d \in Д} B_{d, j}^{c s}+\sum_{i \in \Pi} B_{i, j}+\sum_{R t \in O} B_{R t, j}^{O_{-} \text {sux }}\right) \cdot K_{j, s}^{B x}+M_{j, s}=\left(\sum_{d \in Д} B_{d, j}^{c B}+\sum_{i \in \Pi} B_{i, j}+\sum_{R t \in O} B_{R t, j}^{O_{-} b u x}\right) \cdot K_{j, s}^{B u x} \cdot \\
& i \neq j \\
& i \neq j
\end{aligned}
$$

Water usage: contaminants limiting conditions:

$$
\begin{aligned}
& \forall j, s: K_{j, s}^{B x} \leq K_{j, s}^{B x, \text { Макс },} \\
& \forall j, s: K_{j, s}^{B u x} \leq K_{j, s}^{B u x, \text { Maкc }} .
\end{aligned}
$$

Treated water streams mass balance:

$\forall R t: \quad \sum_{j \in \Pi} B_{j, R t}^{O_{-}{ }^{8 x}}+\sum_{R m \in O} B_{R m, R t}=\sum_{j \in \Pi} B_{R t, j}^{O_{-}{ }^{8 u x}}+\sum_{R n \in O} B_{R t, R n}+B_{R t}^{c m}$.

$$
R t \neq R m \quad R t \neq R n
$$

Water: balance of contaminants:

$$
\begin{gathered}
\forall R t, s: \sum_{j \in \Pi} B_{j, R t}^{O_{-} b x} \cdot K_{j, s}^{B u x}+\sum_{R m \in O} B_{R m, R t} \cdot K_{R m, s}^{B u x}=\left(\sum_{j \in \Pi} B_{j, R t}^{O{ }^{B x}}+\sum_{R m \in O} B_{R m, R t}\right) \cdot K_{R t, s}^{B x} \cdot \\
R t \neq R m \quad R t \neq R m \\
\forall s: \sum_{j \in \Pi} B_{j}^{c m} \cdot K_{j, s}^{B u x}+\sum_{R t \in O} B_{R t}^{c m} \cdot K_{R t, s}^{B u x}=\left(\sum_{j \in \Pi} B_{j}^{c m}+\sum_{R t \in O} B_{R t}^{c m}\right) \cdot K_{s}^{c m}
\end{gathered}
$$


Modeling treatment processes performance:

$\forall R t, s: \quad K_{R t, s}^{B u x}=K_{R t 0, s}^{B u x}$,

or

$$
\begin{array}{lc}
\forall R t, s: & B B_{R t, s}=\frac{K_{R t, s}^{B x}-K_{R t, s}^{B u x}}{K_{R t, s}^{B x}}, \\
\forall R t, s: & B B_{R t, s}=b_{R t 0, s}, \\
\forall R t, s: & K_{R t, s}^{B u x} \leq \kappa_{R t, s}^{B u x, a}, \\
\forall R t, s: & K_{R t, s}^{B x} \leq K_{R t, s}^{B x, a} \cdot \\
\forall s: \quad & K_{R t, s}^{B x}=K_{R t, s}^{B x, o n m},
\end{array}
$$

where: $K_{s}^{c m}$ is concentration of contaminant $s$ in the wastewater; $K_{s}^{c m}$ Макс is guideline value of contaminant $s$ concentration in the wastewater; $K_{j, s}^{B x}$ is concentration of contaminant $s$ at the inlet of water user $j ; K_{j, s}^{B u x}$ is concentration of contaminant $s$ at the outlet of water user $j ; K_{j, s}^{B x, \operatorname{Max}}$ is guideline value of contaminant $s$ concentration at the inlet of water user $j ; K_{j, s}^{B u x, M a x}$ is guideline value of contaminant $s$ concentration at the outlet of water user $j ; K_{R t, s}^{B x}$ is concentration of contaminant $s$ at the inlet of treatment process $R t ; K_{R t, s}^{B u x}$ is concentration of contaminant $s$ at the outlet of treatment process $R t ; \quad K_{R t, s}^{B x, o n m}$ is optimal concentration of contaminant $s$ at the inlet of treatment process $R t ; \quad K_{R t 0, s}^{B u x}$ is predefined value of contaminant $s$ concentration at the outlet of treatment process $R t ; B_{i, j}$ is flow-rate of wastewater from the outlet of water user $i$ to the inlet of water user $j ; B_{R m, R t}$ is flow-rate of partially treated water from the outlet of water treatment process $R m$ to the inlet of water treatment process $R t ; B_{R t}^{c m}$ is flow-rate of wastewater at the outlet of water treatment process $R t ; M_{j, s}$ is mass load of contaminant $s$ at the outlet of water treatment process $R t ; B B_{R t}$ is guideline value of remove ratio of contaminant $s$ (for the treatment process $R t$ ); $B b_{R t, s}$ is current value of remove ratio of contaminant $s$ (for the treatment process $R t$ );

Additional constraints:

$$
\forall j: \quad \sum_{d \in Д} B_{d, j}^{c s}+\sum_{i \in \Pi} B_{i, j}+\sum_{R t \in O} B_{R t, j}^{O{ }_{-} \text {sux }}=B_{j}^{\text {Bum }}, i \neq j
$$


$\begin{array}{lc}\forall j: & B_{j}^{\text {Bum }} \leq B_{j}^{\text {Bum_Макс }}, \\ \forall j: & B_{j}^{\text {Bum }} \geq B_{j}^{\text {Bum_Miн }} .\end{array}$

$\forall d: \quad \sum_{j \in \Pi} B_{d, j}^{c B}-B_{d}^{\text {Makc }}=0$

$\forall R t: \quad B_{R t}^{c m}-y_{R t}^{O_{-} c m} \cdot U \leq 0, R t \in O$,

$\forall j: \quad B_{j}^{c m}-y_{j}^{c m} \cdot U \leq 0, \quad j \in \Pi$.

where: $U$ is limiting value of water re-use flow-rate: $B_{j}^{B m p}$ is water losses in water usage process $j$; $B_{j}^{B u m}$ is flow-rate of fresh water at the inlet of water user $j ; B_{j}^{B u m_{-} \text {MAKC }}$ is limiting (maximal) flowrate of fresh water at the inlet of water user $j ; B_{j}^{B u m_{-} M I H}$ is limiting (minimal) flow-rate of fresh water at the inlet of water user $j ; B_{d}^{M A K C}$ is volume of water supply for freshwater source $d$;

Having found the solution to this problem, we can obtain the optimal structure of the water usage network. However, it is apparent that in order to effectively solve such a complex optimization problem special methods of solution are required.

\section{Water networks design procedure: the choice of means of implementation}

Despite the successful performance in water network design methods there are still problems with their industrial applications. This is due to the fact that existing approaches are aimed at designing the network for fixed (nominal point) data. However, the data they require are highly uncertain in industrial practice. Hence, the network, which is considered optimal for nominal point and current cost parameters, may be expensive or difficult to control and operate under varying conditions in industry. Previously the three-stage procedure to circumvent the problems described above [18] was presented:

1. data preparation by statistical analysis.

2. design of water network using existing approaches, and finally;

3. networks evaluation.

In this contribution we concentrated on the step 2.

The goal functions (1) - (4) coupled with constraints (5) - (23) represents a large mixedinteger nonlinear multi-objective programming problem. In order to solve this optimization problem, the sequential approach (concessions method) was used. The first step is to optimize the fresh water consumption. On the second step (based on the results of the first step), the amount of partially treated water is minimized. In the third step, the pollutant's load on the treatment processes is minimized (per feedback of previous steps).

Calculations were made in MS Excel Solver software.

\section{Case studies}

To date we solved the water network synthesis problem for several data sets from the literature as well as for practical case studies. A few case studies of water networks optimization are provided below. 
Case Study 1. The pulp-and-paper industry water usage network.

Limiting technological data are presented in table 1. Note that this example considers only one contaminant - chemical oxygen demand.

The possible structure of water network corresponding to the results of the design procedure is presented in fig. 2

Table 1. Water usage units (limiting data)

\begin{tabular}{|c|c|c|c|c|c|}
\hline$\#$ & Process & $\begin{array}{c}\text { Mass load } \\
\mathrm{kg} / \mathrm{h}\end{array}$ & $\begin{array}{c}\mathrm{C}_{\mathrm{in}}, \mathrm{mg} \\
\mathrm{O}_{2} / \mathrm{dm}^{3}\end{array}$ & $\begin{array}{c}\mathrm{C}_{\text {out }} \mathrm{mg} \\
\mathrm{O}_{2} / \mathrm{dm}^{3}\end{array}$ & $\begin{array}{c}\text { Freshwater } \\
\text { flow-rate, } \\
\mathrm{m}^{3} / \mathrm{h}\end{array}$ \\
\hline 1 & Pulping & 24800,0 & 500 & 5000 & 5511,1 \\
\hline 2 & Bleach wash & 50,0 & 100 & 400 & 166,7 \\
\hline 3 & Papermaking machine (I) & $-18225,0$ & 5000 & 500 & 4050,0 \\
\hline 4 & Papermaking machine (II) & $-6480,0$ & 5000 & 200 & 1350,0 \\
\hline 5 & Fiber washing & 3,3 & 20 & 100 & 41,6 \\
\hline 6 & Blanket washing & 37,5 & 100 & 500 & 54,2 \\
\hline 7 & Drum washing & 10,0 & 100 & 600 & 125,0 \\
\hline 8 & Mercerization & 4,8 & 200 & 220 & 83,3 \\
\hline 9 & Degumming & 35,4 & 300 & 3700 & 2,1 \\
\hline 10 & Desizing & & & 11394 \\
\hline & Total & & & \\
\hline
\end{tabular}

In the optimized network the amount of wastewater has decreased by $56.18 \%$.

Case Study 2. The pharmaceutical industry water usage network.

Technological input data are presented in tables 2-4. There are sixteen water usage units and four groups of contaminants in the system (table 2 ).

Table 3. Freshwater source data

\begin{tabular}{|c|c|c|c|c|c|}
\hline \multirow{2}{*}{$\#$} & \multirow{2}{*}{ Name of source } & $\begin{array}{c}\text { Matal } \\
\text { suspended } \\
\text { solids, } \\
\mathrm{mg} / \mathrm{dm}^{3}\end{array}$ & $\begin{array}{c}\text { general } \\
\text { hardness, } \mathrm{mg}- \\
\mathrm{eq} / \mathrm{m}^{3}\end{array}$ & $\begin{array}{c}\text { chemical oxygen } \\
\text { demand, } \\
\mathrm{mg} \mathrm{O}_{2} / \mathrm{dm}^{3}\end{array}$ & $\begin{array}{c}\mathrm{salts,} \\
\mathrm{mg} / \mathrm{dm}^{3}\end{array}$ \\
\hline 1 & Tap water & 1,40 & 4,10 & 6,40 & 167,93 \\
\hline
\end{tabular}

Limit values of concentration of contaminants were determined from mass balances or by observation. Instead of reuse costs proportional values (distances between water units) are used (table 4). 
Table 2. Water usage units (limiting data)

\begin{tabular}{|c|c|c|c|c|c|c|c|c|c|c|c|}
\hline \multirow[b]{2}{*}{$\#$} & \multirow[b]{2}{*}{$\begin{array}{c}\text { Water usage } \\
\text { unit }\end{array}$} & \multirow[b]{2}{*}{ 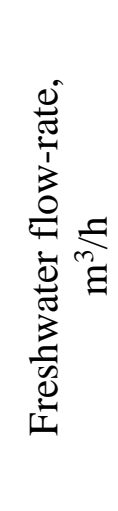 } & \multirow[b]{2}{*}{ 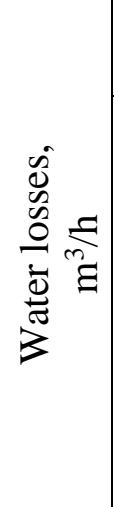 } & \multicolumn{4}{|c|}{ Maximum inlet concentration } & \multicolumn{4}{|c|}{$\begin{array}{l}\text { Maximum outlet } \\
\text { concentration }\end{array}$} \\
\hline & & & & 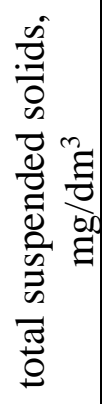 & 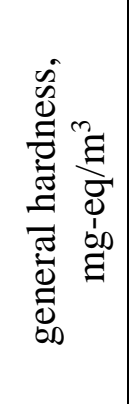 & 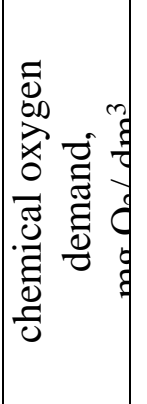 & 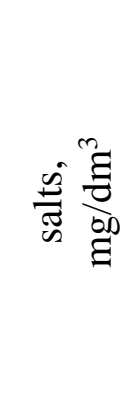 & 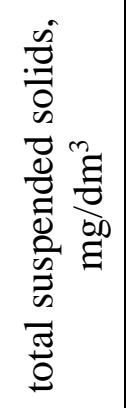 & 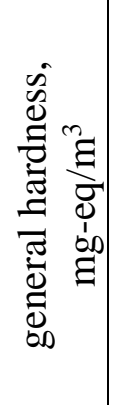 & 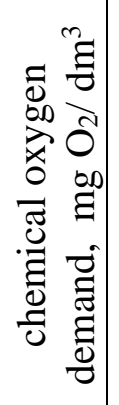 & 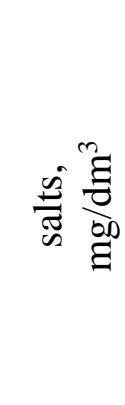 \\
\hline 1 & $\begin{array}{c}\text { Heat } \\
\text { exchanger }\end{array}$ & 20,83 & 1,67 & 23,6 & 4,50 & 55,0 & 900,0 & 30,0 & 5,00 & 70,0 & 1200,0 \\
\hline 2 & $\begin{array}{c}\text { Heat } \\
\text { exchanger }\end{array}$ & 20,83 & 1,67 & 23,6 & 4,50 & 55,0 & 900,0 & 30,0 & 5,00 & 70,0 & 1200,0 \\
\hline 3 & $\begin{array}{c}\text { Heat } \\
\text { exchanger }\end{array}$ & 20,83 & 1,67 & 23,6 & 4,50 & 55,0 & 900,0 & 30,0 & 5,00 & 70,0 & 1200,0 \\
\hline 4 & $\begin{array}{c}\text { Heat } \\
\text { exchanger }\end{array}$ & 15,83 & 1,27 & 23,6 & 4,50 & 55,0 & 900,0 & 30,0 & 5,00 & 70,0 & 1200,0 \\
\hline 5 & $\begin{array}{c}\text { Heat } \\
\text { exchanger }\end{array}$ & 15,83 & 1,27 & 23,6 & 4,50 & 55,0 & 900,0 & 30,0 & 5,00 & 70,0 & 1200,0 \\
\hline 6 & $\begin{array}{c}\text { Heat } \\
\text { exchanger }\end{array}$ & 15,83 & 1,27 & 23,6 & 4,50 & 55,0 & 900,0 & 30,0 & 5,00 & 70,0 & 1200,0 \\
\hline 7 & $\begin{array}{c}\text { Heat } \\
\text { exchanger }\end{array}$ & 15,83 & 1,27 & 23,6 & 4,50 & 55,0 & 900,0 & 30,0 & 5,00 & 70,0 & 1200,0 \\
\hline 8 & $\begin{array}{c}\text { Heat } \\
\text { exchanger }\end{array}$ & 15,83 & 1,27 & 23,6 & 4,50 & 55,0 & 900,0 & 30,0 & 5,00 & 70,0 & 1200,0 \\
\hline 9 & $\begin{array}{c}\text { Heat } \\
\text { exchanger }\end{array}$ & 15,83 & 1,27 & 23,6 & 4,50 & 55,0 & 900,0 & 30,0 & 5,00 & 70,0 & 1200,0 \\
\hline 10 & $\begin{array}{c}\text { Water } \\
\text { preparation } \\
\text { (distillation) } \\
\text { unit } \\
\end{array}$ & 31,50 & 6,30 & 1,45 & 4,100 & 6,41 & 168,0 & 1,5 & 5,95 & 7,53 & 188,0 \\
\hline 11 & \multirow{3}{*}{$\begin{array}{c}\text { Chemical "A" } \\
\text { bottles } \\
\text { washing } \\
\text { machines }\end{array}$} & 27,36 & 2,00 & 1,48 & 4,185 & 7,38 & 170,0 & 19,62 & 5,66 & 8,30 & 175,28 \\
\hline 12 & & 27,36 & 2,00 & 1,48 & 4,185 & 7,38 & 170,0 & 19,62 & 5,66 & 8,30 & 175,28 \\
\hline 13 & & 27,36 & 2,00 & 1,48 & 4,185 & 7,38 & 170,0 & 19,62 & 5,66 & 8,30 & 175,28 \\
\hline 14 & \multirow{2}{*}{$\begin{array}{c}\text { Chemical "B" } \\
\text { bottles } \\
\text { washing } \\
\text { machines }\end{array}$} & 21,96 & 1,00 & 1,48 & 4,185 & 7,38 & 170,0 & 20,67 & 5,20 & 8,36 & 171,50 \\
\hline 15 & & 21,96 & 1,00 & 1,48 & 4,185 & 7,38 & 170,0 & 20,67 & 5,20 & 8,36 & 171,50 \\
\hline 16 & $\begin{array}{l}\text { Steam-boiler } \\
\text { (with ion- } \\
\text { exchange } \\
\text { filter) }\end{array}$ & 112,5 & 112,5 & 1,40 & 4,15 & 6,41 & 167,93 & - & - & - & - \\
\hline
\end{tabular}




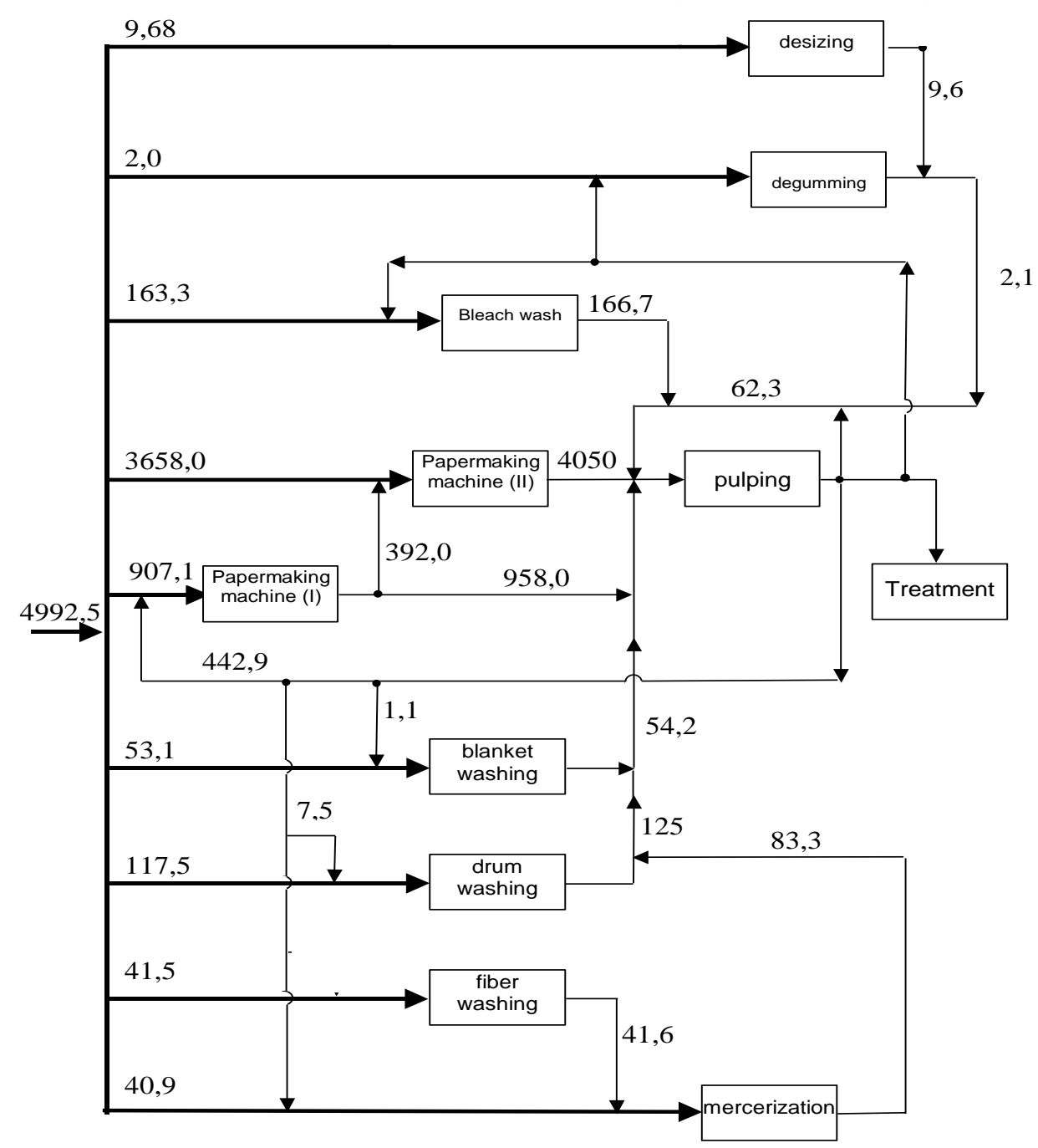

Fig. 2. Possible structure of water network of pulp and paper plant

Table 4. Distances between water usage units, $\mathrm{m}$

\begin{tabular}{|l|l|l|l|l|l|l|l|l|l|l|l|l|l|l|l|l|}
\hline & 1 & 2 & 3 & 4 & 5 & 6 & 7 & 8 & 9 & 10 & 11 & 12 & 13 & 14 & 15 & 16 \\
\hline 1 & 0 & 20 & 23 & 26 & 18 & 20 & 100 & 17,4 & 16,3 & 15 & 40,5 & 38 & 36 & 34 & 32,5 & 30 \\
\hline 2 & & 0 & 3 & 6 & 20 & 21,5 & 120 & 37,2 & 36,2 & 35 & 55 & 53 & 52 & 50 & 52,5 & 50 \\
\hline 3 & & & 0 & 3 & 23 & 24,5 & 123 & 40,4 & 39,2 & 38 & 58 & 56 & 55 & 53 & 55,5 & 53 \\
\hline 4 & & & & 0 & 26 & 27,5 & 126 & 43,4 & 42,2 & 41 & 61 & 59 & 58 & 56 & 58,5 & 56 \\
\hline 5 & & & & & 0 & 2 & 118 & 20 & 19 & 18 & 38 & 36 & 35 & 32 & 34 & 32 \\
\hline 6 & & & & & & 0 & 120 & 19 & 18 & 18 & 35 & 32 & 32 & 32 & 35 & 34 \\
\hline 7 & & & & & & & 0 & 119 & 120 & 119 & 134 & 135 & 135 & 138 & 138 & 140 \\
\hline 8 & & & & & & & & 0 & 1,2 & 2,4 & 15 & 15 & 18 & 20 & 22 & 24 \\
\hline 9 & & & & & & & & & 0 & 1,2 & 17 & 15 & 17 & 18 & 20 & 22 \\
\hline 10 & & & & & & & & & & 0 & 20 & 18 & 17 & 15 & 16 & 17 \\
\hline 11 & & & & & & & & & & & 0 & 2,5 & 5 & 7,5 & 10 & 12,5 \\
\hline 12 & & & & & & & & & & & & 0 & 2,5 & 5 & 7,5 & 10 \\
\hline 13 & & & & & & & & & & & & & 0 & 2,5 & 5 & 7,5 \\
\hline 14 & & & & & & & & & & & & & & 0 & 2,5 & 5 \\
\hline 15 & & & & & & & & & & & & & & & 0 & 2,5 \\
\hline 16 & & & & & & & & & & & & & & & & 0 \\
\hline
\end{tabular}


The possible structure of water network of the pharmaceutical plant is presented in fig. 3 . To increase the reliability of network in this case the re-used water tanks were applied.

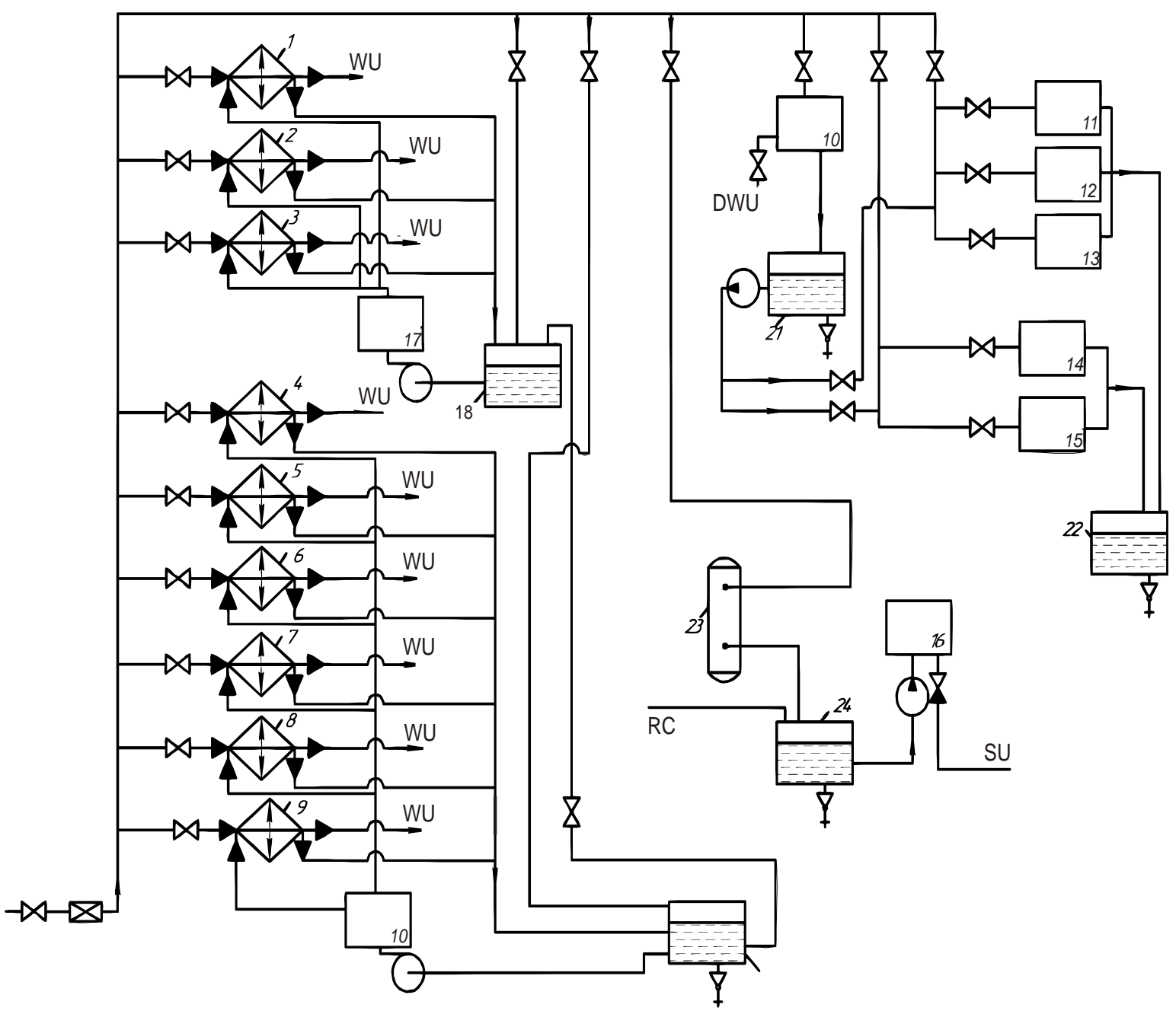

Fig. 3. Possible structure of water network of pharmaceutical plant:

1-9 - heat exchangers; 10 - Water preparation (distillation) unit; 11-13 - Chemical "A" bottles washing machines; 14, 15 - Chemical "B" bottles washing machines; 16 -Steam-boiler; 17, 19 Heaters; 18, 20-22 - Re-used water tank; 23 - ion-exchange filter; 24 - Condensate tank; RC return the condensate from steam users; SU -to steam users; WU - to water users; DWU - to distilled water users.

In the optimized network the amount of wastewater has decreased from $10835 \mathrm{~m}^{3} /$ day to 8509 $\mathrm{m}^{3} /$ day $(21 \%$.)

\section{Summary}

Simultaneous procedure for designing optimal water usage network has been developed above. The present authors strongly believe that optimization-based methods of designing usage networks together with computer software are very promising. Appearingly, simultaneous approaches will not be fully automated in order to allow the designer to have control over the process being designed. Also, they need some sequential strategy in generally simultaneous framework. Such the inference can be drawn from analysis of suggested current approaches and industrial needs. Further research should combine different procedures to create a common one, which will consider the interaction of subsystems (such as HENs, MENs, WNs and so on) in the integrated total chemical site. 


\section{Acknowledgments}

The paper presented is part of an ongoing research project "Development of sustainable industrial water networks" (state registration No 0117U005297).

This paper is dedicated to the memory of Prof. Jacek Jeżowski (Rzeszów University of Technology) and Prof. Gennady Statyukha (National Technical University of Ukraine, "Kyiv Polytechnic Institute, elder friends and respected colleagues.

\section{ПРОЦЕДУРА ПРОЕКТУВАННЯ СХЕМ ПРОМИСЛОВОГО ВОДОСПОЖИВАННЯ.}

\section{А. Шахновський, О. Квітка}

Національний технічний університет України "Київський політехнічний інститут ім. Ігоря Сікорського", Київ, Україна, e-mail: kxtp@kpi.ua

У роботі розглядаються деякі результати досліджень щодо створення процедур оптимального проектування промислових схем водоспожсивання відповідно до парадигми «інтегрування прочесів». Мета досліджень - досягнення обтрунтованого мінімуму обсягів споживання свіжої води технологічною схемою шляхом впровадження повторнобататоразового водоспоживання за умов оптимальної кількості технологічних взаємозв'язків між прочесами водоспоживання та водоочищення.

Проаналізовано доцільність використання у випадку підсистем водоспоживання існуючих «ієрархічних» та «послідовних» конџепцій проектування хіміко-технологічних систем на принципах інтегрування прочесів. За результатами аналізу обрано підхід, заснований на виріменні математичної задачі оптимізації (вказаний “одночасний”, або ж “надструкурний” підхід носить у вітчизняній літературі також назву методу структурних параметрів).

У роботі представлено загальний алгоритм вирімення задачі оптимізації, який включає етапи попереднього аналізу та підготування вихідних даних, синтезу структури схеми водоспоживання, підготування до промислової імплементації. Описано розроблену на основі вказаного алгоритму процедуру оптимального проектування схем водоспоживання.

У межах задач дослідження, у роботі обтрунтовано вибір математичного апарату. Пропонована у роботі прочедура проектування схем промислового водоспоживання базується на вирішенні задачі змішано-иілочисельного умовного нелінійного багаточільового програмування, складеної на основі узагальненої схеми системи водоспоживання (“надструктури водоспоживання”). Узагальнена схема включає всі можливі варіанти структури схеми водоспоживання і виходить із матеріальних балансів складових частин технологічної схеми водоспоживання: змімувачів та дільників потоків, прочесів водоспоживання та процесів часткового очищення води.

Наведені характерні приклади оптимізації систем водоспоживання покликані продемонструвати ефективність пропонованої обчислювальної процедури для оптимального синтезу схем водоспоживання.

Ключові слова: схема водоспоживання, проектування, стічні води, оптимізація, задача математичного програмування. 


\section{ПРОЦЕДУРА ПРОЕКТИРОВАНИЯ СХЕМ ПРОМЫШЛЕННОГО ВОДОПОТРЕБЛЕНИЯ.}

\section{А. Шахновский, А. Квитка}

Национальный технический университет Украины "Киевский политехнический институт им. Игоря Сикорского", Киев, Украина, e-mail: kxtp@kpi.ua

В работе рассматриваются некоторые результать исследований относительно оптимального проектирования схем водопотребления. Цель исследований - минимизация потребления свежей воды путем внедрения повторно-многократного водопотребления в условиях оптимального количества технологических взаимосвязей между процессами водопотребления и водоочистки. Подход $\kappa$ проектированию основан на решении математической задачи смешанно-целочисленного нелинейного многочелевого программирования. Задача оптимизации базируется на обобщенной схеме системь водопотребления. Обобщенная схема включает все возможные варианты структуры и включает и исходит из материальных балансов смесителей и делителей потоков, водопотребителей и прочессов частичной очистки воды. Представлен общий алгоритм решения задачи оптимизачии. Описана прочедура оптимального проектирования схем водопотребления. Приведенные примеры показывают, что подход является эффективной техникой для оптимального синтеза схем водопотребления.

Ключевые слова: схема водопотребления, проектирование, сточные воды, оптимизачия, задача математического программирования.

\section{REFERENCES}

1. Wang Y.P, Smith R. Wastewater minimization. Chem. Engineering Science. 1994. 49(7). 981-1006.

2. Statyukha G., Kvitka A., Shakhnovsky A. Use of the water pinch analysis method to the design of industrial water usage networks. KPI Science News. 2003. No. 2. 125-131. [In Ukrainian]

3. Foo D. State-of-the-Art Review of Pinch Analysis Techniques for Water Network Synthesis. Ind. Eng. Chem. Res. 2009. 48. 5125-5159

4. Takama N., Kiriyama T., Shiroko K., Umeda T. Optimal water allocation in a petroleum refinery. Comput. Chem. Eng. 1980. No. 4. 251-258.

5. Shakhnovskij A., Jeżowski J., Kvitka A., Jeżowska A., Statiukha G. Investigation of the optimization of process water network using mathematical programming. Inżynieria chemiczna $\mathrm{i}$ procesowa. 2001. 22. 200-500. [In Polish]

6. Jeżowski J. Review of Water Network Design Methods with Literature Annotations. Industrial \& Engineering Chemistry Research. 2010. 49. 4475-4516.

7. Shakhnovsky A., Jeżowski J., Statyukha G., Kvitka A. The problem of optimality in industrial water usage networks design. KPI Science News. 2004. No. 6. 35-41. [In Ukrainian]

8. Manousiouthakis A., Allen D. Process Synthesis for Waste Minimization. Fourth International Conference on Foundations of Computer-Aided Process Design. (Snowmass, Colorado, July 10-14, 1994). AIChE Symposium Series; AIChe: New York. 91. 256-259.

9. Furman K. C., Sahinidis N. V. A critical revue and annotated bibliography for heat exchanger network synthesis in the 20th century. Industrial \& Engineering Chemistry Research. 2002. 41, 23352370

10. Hamad A., El-Halwagi M. Simultaneous Synthesis of Mass Separating Agents and Interception Networks. Chemical Engineering Research and Design. 199876 (3). 376-388. 
11. Statyukha G., Kvitka A., Shakhnovsky A. Modeling industrial water usage networks based on the superstructure method. Eco-technology and resource-saving. 2003. No. 5. 57-62. [In Ukrainian]

12. Feng X., Bai J., Wang H., Zheng X. Grass-roots design of regeneration recycling water networks. Computers \& Chemical Engineering. 2008. 32(8). 1892-1907.

13. Faria D.C., Souza A., Arruda S. M, Souza G.U. Optimization of water networks in industrial processes. Journal of Cleaner Production. 2009. 17. 857-862.

14. Matijasevic L., Dejanovic I., Spoja D. A water network optimization using MATLAB-A case study. Resources, Conservation and Recycling. 2010. 54. 1362-1367.

15. Koppol A., Bagajewicz M., Dericks B., Savelski M. On zero water discharge solutions in the process industry. Advances in Environmental Research. 2003. 8. 151-171.

16. Lim S., Park D., Park J. M. Analysis of effects of an objective function on environmental and economic performance of a water network system using life cycle assessment and life cycle costing methods. Chemical Engineering Journal. 2008. 144. 368-378.

17. Tiana J.R., Zhoua P.J., Lv B. A process integration approach to industrial water conservation: A case study for a Chinese steel plant. Journal of Environmental Management. 2008. 86. 682-687.

18. Statyukha G., Shakhnovsky A., Jeżowski J., Jeżowska A., Kvitka A. A methodology for designing industrial water networks. Chemical Engineering Transactions. 2009. No. 18. 189-194. 